Tropical Journal of Pharmaceutical Research November 2021; 20 (11): 2339-2346

ISSN: $1596-5996$ (print); 1596-9827 (electronic)

(C) Pharmacotherapy Group, Faculty of Pharmacy, University of Benin, Benin City, 300001 Nigeria

Original Research Article

http://dx.doi.org/10.4314/tjpr.v20i11.16

\title{
Effects of Sargassum plagiophyllum extract pretreatment on tissue histology of constipated mice
}

\author{
Rattanaporn Sengkhim¹, Saranya Peerakietkhajorn ${ }^{1,2}$, Nilobon Jeanmard ${ }^{1}$, \\ Supattra Pongparadon ${ }^{3}$, Pissared Khuituan ${ }^{2,4}$, Thanvarin Thitiphatphuvanon ${ }^{5}$, \\ Piyaporn Surinlert ${ }^{6}$, Chittipong Tipbunjong ${ }^{2,7 *}$ \\ ${ }^{1}$ Department of Biology, Division of Biological Science, Faculty of Science, ${ }^{2}$ Gut Biology and Microbiota Research Unit, \\ ${ }^{3}$ Excellence Center for Biodiversity of Peninsular Thailand, Faculty of Science, Prince of Songkla University, ${ }^{4}$ Department of \\ Physiology, Division of Health and Applied Sciences, Faculty of Science, Prince of Songkla University, Songkhla 90110, \\ ${ }^{5}$ Faculty of Medicine, Siam University, Bangkok 10160, ${ }^{6}$ Chulabhorn International College of Medicine, Thammasat University, \\ Pathum-Thani 12120, ${ }^{7}$ Department of Anatomy, Division of Health and Applied Sciences, Faculty of Science, Prince of Songkla \\ University, Songkhla 90110, Thailand
}

*For correspondence: Email: chittipong.t@psu.ac.th

Sent for review: 27 May 2021

Revised accepted: 15 October 2021

\begin{abstract}
Purpose: To evaluate the toxicity of the dried seaweed, Sargassum plagiophyllum, extract (SPE) pretreatment in constipated mice.

Methods: The dried seaweed powder was mixed with distilled water and extracted by autoclave at 121 ${ }^{\circ} \mathrm{C}$. Antioxidant activity of the extract was determined by 2,2-diphenyl-1-picrylhydrazyl (DPPH) assay. Human normal colon cells were pretreated with SPE at $0-100 \mu \mathrm{g} / \mathrm{mL}$ for $24 \mathrm{~h}$ before challenging them with $100 \mu \mathrm{M}$ hydrogen peroxide $\left(\mathrm{H}_{2} \mathrm{O}_{2}\right)$. Intracellular reactive oxygen species (ROS) were quantified using 2',7'-dichlorodihydrofluorescein diacetate $\left(\mathrm{H}_{2} \mathrm{DCFDA}\right)$. Male ICR mice were pretreated for 14 consecutive days with SPE at 100,500 and 1,000 mg/kg or lactulose at $500 \mathrm{mg} / \mathrm{kg}$. Body weight and food intake were recorded daily. Constipation was induced with loperamide on days 12, 13 and 14 and fecal pellets evacuated over a 4-hr period. The ileum, liver, kidney, and spleen were collected for histopathological examination.

Results: The IC50 for the radical scavenging capacity of SPE was $343.90 \pm 4.21 \mu \mathrm{g} / \mathrm{mL}$ compared to $14.14 \pm 0.71 \mu \mathrm{g} / \mathrm{mL}$ for ascorbic acid. Pretreatment with SPE was significantly reduced ROS production in human normal colon cells. Oral administration of all doses of SPE and lactulose for 14 consecutive days had no effect on food intake or body weight when compared to the normal control group. Defecation was significantly more frequent in mice pretreated with SPE at $100 \mathrm{mg} / \mathrm{kg}$ than in the constipation control group. Histopathological examination of the ileum, liver, kidney and spleen of pretreated constipated mice revealed no toxic effect from either SPE or lactulose. On the other hand, the loss of mucus-producing cells in the ileum of constipated mice was significantly lower in mice pretreated with SPE.

Conclusions: These findings support the safety of SPE supplementation and may broaden its application in clinical fields as an alternative drug or supplement for constipation management.
\end{abstract}

Keywords: Sargassum plagiophyllum, Constipation, Prebiotics, Seaweed, Antioxidant

This is an Open Access article that uses a funding model which does not charge readers or their institutions for access and distributed under the terms of the Creative Commons Attribution License (http://creativecommons.org/licenses/by/4.0) and the Budapest Open Access Initiative (http://www.budapestopenaccessinitiative.org/read), which permit unrestricted use, distribution, and reproduction in any medium, provided the original work is properly credited.

Tropical Journal of Pharmaceutical Research is indexed by Science Citation Index (SciSearch), Scopus, International Pharmaceutical Abstract, Chemical Abstracts, Embase, Index Copernicus, EBSCO, African Index Medicus, JournalSeek, Journal Citation Reports/Science Edition, Directory of Open Access Journals (DOAJ), African Journal Online, Bioline International, Open-J-Gate and Pharmacy Abstracts 


\section{INTRODUCTION}

Constipation is a common gastrointestinal problem characterized by infrequent stools, difficult stool passage, or both. It causes discomfort and affects quality of life. Common causes of constipation include medications, metabolic abnormalities, and age. The prevalence of constipation increases gradually after the age of 50 and rapidly after the age of 70 [1]. The deleterious effects of constipation can be treated or relieved by different drugs. Among these, linaclotide and lubiprostone are well known, but long-term use commonly produces adverse effects. To enable the management of constipation without the side effects of conventional drugs, attention has gradually turned to the development of medicinal plant extracts with prebiotic properties. The administration of prebiotics has been reported to relieve constipation in patients by increasing stool frequency and improving stool consistency [2]. The possible mode of action may be alteration of gut motility due to stimulation of the colonic microbiota [3]. A known medicinal plant, brown seaweed (e.g. Sargassum polycystum, Sargassum ilicifolium, Sargassum plagiophyllum, etc.) is widely distributed in coastal areas of Thailand and has long been used in the diet and folk medicine of Asian countries [4]. Extracts from Sargassum sp. were reported to exhibit not only prebiotic but also antioxidant activities [5]. Antioxidants promote physiological wellbeing by counteracting oxidative stress and mitigating the pathogenesis of disease conditions. Moreover, extracts of Sargassum sp. have also been reported to possess neuroprotective, hepatoprotective, anti-inflammatory, anti-cancer, and immunomodulatory properties [6].

In order to develop a seaweed extract as an alternative treatment for constipation, it is vital to strengthen its medicinal viability by ruling out any potential toxicity. Although Sargassum plagiophyllum was reported to be abundant on the west coast of Thailand, there is no existing toxicity profile and the antioxidant activity of $S$. plagiophyllum extract has not been reported. Therefore, the present study aims to evaluate the antioxidant and biochemical activities of $S$. plagiophyllum extract, and any toxic effect on the ileum, kidney, liver, and spleen of constipated mice.

\section{EXPERIMENTAL}

\section{Materials}

Unless otherwise indicated, basic chemicals, loperamide and lactulose were purchased from
Sigma-Aldrich (Saint Louis, MO, USA). Cell culture reagents were from Gibco (Life Technologies, Carlsbad, CA, USA). Human normal colon cells were kindly provided by Dr. Supansa Kongseng, Prince of Songkla University, Thailand.

\section{Preparation of the Sargassum plagiophyllum extract (SPE)}

Adult stage S. plagiophyllum was harvested from Lanta Island, Krabi, Thailand. S. plagiophyllum was washed with distilled water, dried at $60{ }^{\circ} \mathrm{C}$ for $48 \mathrm{~h}$, and pulverised. To prepare the SPE, 10 $\mathrm{g}$ of dried $\mathrm{S}$. plagiophyllum powder were mixed with $1 \mathrm{~L}$ of distilled water and the mixture was autoclaved at $121{ }^{\circ} \mathrm{C}$ for $20 \mathrm{~min}$. The autoclaved mixture was filtered through cheesecloth. The filtrate was centrifuged at $2,220 \mathrm{~g}$ for $10 \mathrm{~min}$. The supernatant was collected and freeze dried (CHRIST, DELTA 2-24 LSCplus, Germany).\#

\section{2,2-Diphenyl-1-picrylhydrazyl (DPPH) assay}

Free radical scavenging capacity was determined by using DPPH radicals. Briefly, 100 $\mu \mathrm{L}$ of $400 \mu \mathrm{M}$ DPPH solution dissolved in methanol were mixed with $100 \mu \mathrm{L}$ of SPE or ascorbic acid at the desired concentration. The mixture was incubated for $30 \mathrm{~min}$ at room temperature and then absorbance was measured at $517 \mathrm{~nm}$ with a microplate reader (Synergy HT; BioTek, USA). The percentage radical scavenging capacity (RSC) was calculated as in Eq 1.

$\operatorname{RSC}(\%)=\{100-($ Aed $-\mathrm{Ae}) / \mathrm{Ac})\} 100 \ldots(1)$

where Aed is the absorbance of the extract with $\mathrm{DPPH} ; \mathrm{Ae}$ is the absorbance of the extract alone; and $A c$ is the absorbance of DPPH alone. RSC was expressed as $50 \%$ inhibition concentration $\left(\mathrm{IC}_{50}\right)$.

\section{Cell culture and reactive oxygen species (ROS) production assay}

Human normal colon cells were cultured in growth medium (GM) composed of Dulbecco's modified Eagle medium (DMEM) supplemented with $10 \%$ fetal bovine serum (FBS) in a humidified $\mathrm{CO}_{2}$ incubator at $37{ }^{\circ} \mathrm{C}$. For the ROS production assay, human normal colon cells were seeded into 96-well plates at 5000 cells/well and allowed to grow for $24 \mathrm{~h}$. The cells were pretreated with 0-100 $\mu \mathrm{M}$ SPE in GM for 24 h. $\mathrm{H}_{2} \mathrm{O}_{2}$ was directly added to each well for a final concentration of $100 \mu \mathrm{M}$. After incubation for $6 \mathrm{~h}$, the medium was discarded. The cells were then incubated at $37{ }^{\circ} \mathrm{C}$ for $30 \mathrm{~min}$ with $10 \mu \mathrm{M}$ 
$\mathrm{H}_{2}$ DCFDA in phosphate buffer saline (PBS). After washing the cells several times with PBS, fluorescence intensity was measured at $485 \mathrm{~nm}$ excitation and $535 \mathrm{~nm}$ emission wavelengths using a fluorescence microplate reader (Synergy HT; BioTek, USA).

\section{Animals and treatment groups}

Male ICR mice (Mus musculus; 6 weeks old, weighing 30 - $35 \mathrm{~g}$ ) were obtained from the National Laboratory Animal Center and housed at the Southern Laboratory Animal Facility, Thailand. All mice were acclimatized for 7 days before the experiment started. They were placed in stainless steel cages, kept under standard environmental conditions at $23-27^{\circ} \mathrm{C}$ with $50-$ $55 \%$ humidity under a 12-hour light/12-hour dark cycle. They were given standard commercial food pellets and reverse osmosis purified water ad libitum.

The mice were randomly divided into 6 groups: a normal control, a constipation control, a positive control constipation group that received 500 $\mathrm{mg} / \mathrm{kg}$ lactulose, and three constipation groups that received different doses of SPE $(100,500$, and $1000 \mathrm{mg} / \mathrm{kg}$ ). The treatments were administered once a day for 14 days. On days 12, 13 and 14, constipation was induced in all groups, except the normal control, by oral administration of loperamide at a dose of 5 $\mathrm{mg} / \mathrm{kg}$ body weight. Body weight and food intake were recorded daily. Fecal pellets evacuated over a four-hour period were counted and hourly averages calculated. This study was approved by the Animal Ethics Committee of Prince of Songkla University, Thailand (ethical clearance no. MOE 0521.11/1555, Ref.68/2018) and followed international guidelines for animal studies.

\section{Histopathological examination}

After treatment with SPE once a day for 14 days and with loperamide on days 12, 13, and 14, the mice were sacrificed by sodium thiopental injection. The ileum, kidney, liver, and spleen were immediately excised, cut into small pieces, and fixed with $10 \%$ formalin for $24 \mathrm{~h}$. The fixed tissues were dehydrated with a graded ethanol series, embedded in paraffin blocks, and sectioned at $5 \mu \mathrm{m}$ thickness. The sections were stained with hematoxylin and eosin ( $H$ \& $E)$, periodic acid-Schiff (PAS) and Masson's trichrome following the standard protocols. The change in epithelial and cellular morphology, number of goblet cells, and accumulation of collagen fiber in stained tissues were examined under a light microscope (Olympus DP73).

\section{Statistical analysis}

The data from at least 4 independent experiments were presented as means \pm standard error of the mean (SEM). Statistical differences were analyzed by one-way analysis of variance (ANOVA), followed by the Bonferroni test using GraphPrism (version 5). The data were considered statistically significant when $p<0.05$.

\section{RESULTS}

\section{Antioxidant activity of SPE}

The yield of SPE extracted by autoclave was $23.46 \pm 0.26 \%$ of dried weight. An in vitro assay revealed that the antioxidant activity of SPE was concentration-dependent (Figure 1). The $\mathrm{IC}_{50}$ for the RSC of SPE was $343.90 \pm 4.21 \mu \mathrm{g} / \mathrm{mL}$ whereas the $\mathrm{IC}_{50}$ for the RSC of the standard ascorbic acid was $14.14 \pm 0.71 \mu \mathrm{g} / \mathrm{mL}$ (Figure 1 A). Moreover, ROS production in human normal colon cells after stimulation with $100 \mu \mathrm{M} \mathrm{H} \mathrm{H}_{2} \mathrm{O}_{2}$ was significantly lower after pretreatment with SPE at $10-100 \mu \mathrm{g} / \mathrm{mL}$ for $24 \mathrm{~h}$ (Figure $1 \mathrm{~B}$ ).

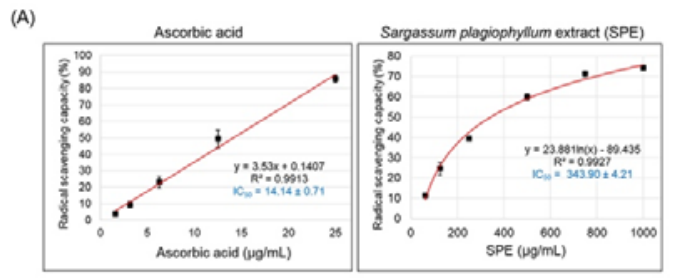

(B)

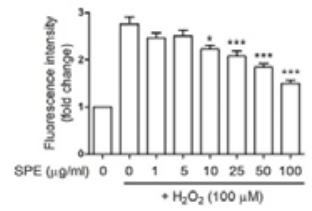

Figure 1: Antioxidant activity of Sargassum plagiophyllum extract (SPE) (A) and effect of SPE pretreatment on reactive oxygen species (ROS) production in human normal colon cells (B). ${ }^{*} p<0.05$, ${ }^{* *} p<0.01,{ }^{* *} p<0.001$ compared to $\mathrm{H}_{2} \mathrm{O}_{2}$-treated control

\section{Effect of SPE pretreatment on food intake,} body weight and constipation

Changes in body weight and feeding activity were used as an indicator of the toxic effects of SPE. Up to the fourteenth day, there was no significant difference between the body weights of mice in all six groups (Table 1). Body weight was consistent with food intake, which also did not significantly change throughout the experiment (Table 2). However, the frequency of defecation did vary among groups. The

Trop J Pharm Res, November 2021; 20(11): 2341 
Table 1: Effect of SPE pretreatment on body weight in constipated mice

\begin{tabular}{lcccc}
\hline \multirow{2}{*}{ Treatment } & \multicolumn{4}{c}{ Body weight $(\mathbf{g})$} \\
\cline { 2 - 5 } & Day 1 & Day 5 & Day 9 & Day 13 \\
\hline Normal control & $37.05 \pm 1.37$ & $36.90 \pm 1.01$ & $36.86 \pm 1.02$ & $37.04 \pm 1.00$ \\
Constipation control & $38.01 \pm 0.42$ & $38.18 \pm 0.47$ & $38.20 \pm 0.57$ & $37.75 \pm 0.78$ \\
Lactulose $(500 \mathrm{mg} / \mathrm{kg})+$ constipation & $35.20 \pm 0.77$ & $36.31 \pm 0.88$ & $36.73 \pm 0.62$ & $36.84 \pm 0.60$ \\
SPE $(100 \mathrm{mg} / \mathrm{kg})+$ constipation & $39.09 \pm 1.46$ & $39.18 \pm 1.49$ & $39.46 \pm 1.43$ & $39.95 \pm 1.44$ \\
SPE $(500 \mathrm{mg} / \mathrm{kg})+$ constipation & $38.00 \pm 0.80$ & $37.84 \pm 1.08$ & $38.55 \pm 1.21$ & $39.43 \pm 1.20$ \\
SPE $(1000 \mathrm{mg} / \mathrm{kg})+$ constipation & $39.70 \pm 1.33$ & $39.80 \pm 1.48$ & $39.79 \pm 1.32$ & $40.36 \pm 1.28$ \\
\hline
\end{tabular}

Values are expressed as means \pm S.E.M

Table 2: Effect of SPE pretreatment on food intake in constipated mice

\begin{tabular}{lcccc}
\hline \multirow{2}{*}{ Treatment } & \multicolumn{4}{c}{ Food intake (g) } \\
\cline { 2 - 5 } & Day 1 & Day 5 & Day 9 & Day 13 \\
\hline Normal control & $4.56 \pm 0.18$ & $4.76 \pm 0.10$ & $4.60 \pm 0.09$ & $4.66 \pm 0.11$ \\
Constipation control & $4.46 \pm 0.07$ & $4.29 \pm 0.13$ & $4.18 \pm 0.13$ & $4.02 \pm 0.03$ \\
Lactulose $(500 \mathrm{mg} / \mathrm{kg})+$ constipation & $4.76 \pm 0.28$ & $4.84 \pm 0.10$ & $4.44 \pm 0.10$ & $4.13 \pm 0.06$ \\
SPE $(100 \mathrm{mg} / \mathrm{kg})+$ constipation & $5.14 \pm 0.08$ & $4.55 \pm 0.17$ & $4.56 \pm 0.14$ & $4.04 \pm 0.19$ \\
SPE $(500 \mathrm{mg} / \mathrm{kg})+$ constipation & $4.06 \pm 0.19$ & $4.85 \pm 0.31$ & $4.61 \pm 0.24$ & $4.63 \pm 0.25$ \\
SPE $(1000 \mathrm{mg} / \mathrm{kg})+$ constipation & $4.83 \pm 0.24$ & $4.72 \pm 0.21$ & $4.62 \pm 0.14$ & $4.64 \pm 0.16$ \\
\hline
\end{tabular}

Values are expressed as means \pm S.E.M

Table 3: Effect of SPE pretreatment on the frequency of defecation in constipated mice

\begin{tabular}{lc}
\hline Treatment & $\begin{array}{c}\text { Frequency of } \\
\text { defecation }\end{array}$ \\
\cline { 2 - 2 } (pellet/hour)
\end{tabular}

Effect of SPE pretreatment on the intestinal epithelium architecture of constipated mice

There was no difference in the epithelium of the ileum among all experimental groups (Figure 2 A). The epithelial lining remained simple columnar with goblet cells, which is the normal characteristic of the digestive tract. Further investigation of the epithelial architecture of SPE and lactulose pretreatment groups and the constipation control group revealed no change in the appearance of either villi or crypts. The length of villi (Figure $2 \mathrm{~B}$ ), depth of crypts (Figure $2 \mathrm{C}$ ), and villus length-crypt depth ratio (Figure 2 D) showed no significant difference among all groups.

\section{Effect of SPE pretreatment on the number of mucus-producing cells in the ileum}

Periodic acid Schiff (PAS) staining was used to aid the investigation of the protective effect of SPE pretreatment on the number of mucusproducing cells, or goblet cells, in constipated mice. The goblet cells located in the epithelium of villi and crypts were stained dark pink (Figure 3 A). The numbers of goblet cells per villus (Figure $3 \mathrm{C}$ ), but not per crypt (Figure $3 \mathrm{~B}$ ), were significantly reduced in the constipation control group compared to the normal control group. All three SPE pretreatment groups showed significantly higher numbers of goblet cells per villus compared to the constipation control group (Figure 3C).

\section{Effect of SPE pretreatment on the kidney histology of constipated mice}

The kidneys are responsible for the elimination of toxic agents. In the application of herbal extracts, the development of renal toxicity is a major limiting factor. This study showed that supplementation with SPE at 100, 500, and 1000 $\mathrm{mg} / \mathrm{kg}$ and lactulose at $500 \mathrm{mg} / \mathrm{kg}$ for 14 consecutive days did not produce any signs of renal toxicity (Figure 4). There was no glomerulus atrophy and urinary space dilation in all treatment groups. Also, the epithelial thickness of proximal and distal convoluted 


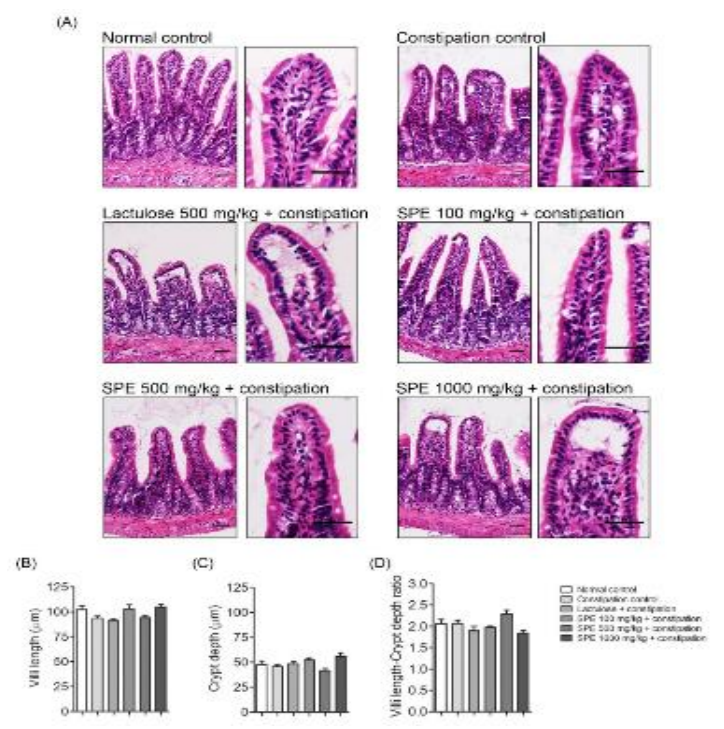

Figure 2: Effect of Sargassum plagiophyllum extract (SPE) pretreatment on the architecture of the ileal mucosa in constipated mice (A). The length of villi $(B)$ and depth of crypts (C) were measured. The ratios of villus length-crypt depth were calculated (D). Scale bar $=20 \mu \mathrm{m}$

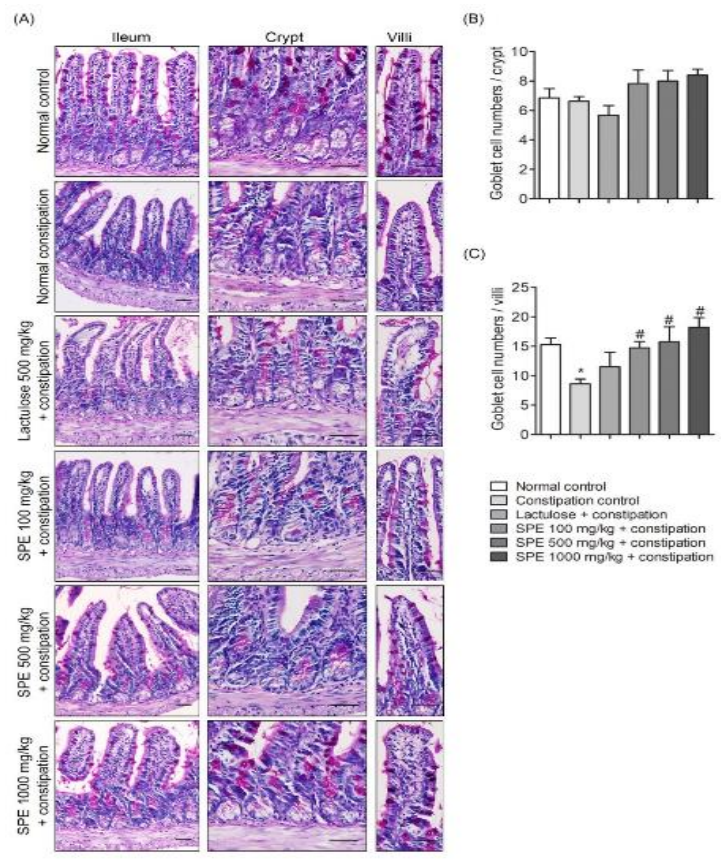

Figure 3: Effect of Sargassum plagiophyllum extract (SPE) pretreatment on numbers of goblet cells in the ileum of constipated mice (A). Numbers of goblet cells were determined per crypt (B) and per villus (C). ${ }^{*} p<$ 0.05 compared to normal control, ${ }^{\#} p<0.05$ compared to constipation control, scale bar $=20 \mu \mathrm{m}$

tubules and brush borders of proximal tubules was not affected.
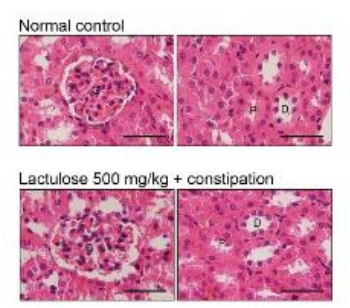

SPE $500 \mathrm{mg} / \mathrm{kg}+$ constipation
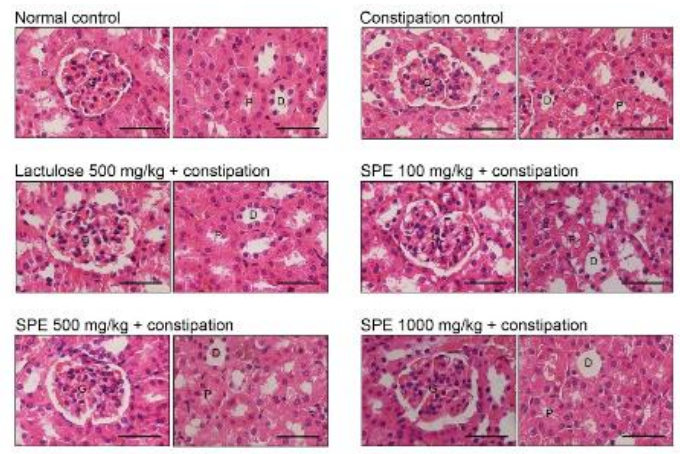

$\mathrm{SPE} 100 \mathrm{mg} / \mathrm{kg}+$ constipation

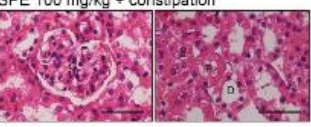

SPE $1000 \mathrm{mg} / \mathrm{kg}+$ constipation

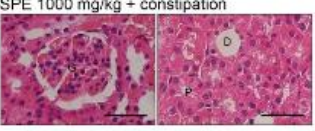

Figure 4: Effects of Sargassum plagiophyllum extract (SPE) pretreatment on the kidney histology of constipated mice. The kidney tissues were stained with hematoxylin and eosin (H\&E). G: glomerulus; P: proximal tubule; D: distal tubule; scale bar $=20 \mu \mathrm{m}$

\section{Effect of SPE pretreatment on the liver histology of constipated mice}

Histological changes in the liver, the organ essential for metabolism and glycogen storage, were investigated. After histopathological assessment, comparison with the control groups revealed that no significant morphological changes had occurred in the liver tissue of all three SPE pretreatment groups and the lactulose pretreatment group (Figure 5). Liver tissue from all groups showed regular hepatic lobules with central veins and peripheral portal triads. Normal hepatocytes and hepatic cords extended radially from the central veins. The sinusoidal spaces in each group were the same. PAS staining showed abundant distributions of glycogen granules within the cytoplasm of hepatocytes in all groups. Masson's trichrome staining revealed small collagen fiber deposits supporting structures in the portal triad; branch of portal vein, hepatic artery, and bile ducts. Increases in collagen fiber deposits have been used as an index to evaluate liver injury and drug and chemical hepatotoxicity. However, after 14-days of treatment with SPE and lactulose, the amount of collagen fiber in the portal triad of mice in those groups showed no change compared to mice in the normal control and constipation control groups.

\section{Effect of SPE pretreatment on the spleen histology of constipated mice}

Histopathological examination of spleen tissue revealed normal histology in all groups (Figure 6 ). There was no evidence of splenic hyperplasia or splenic volume loss in any SPE pretreatment group nor in the lactulose pretreatment group. Furthermore, lymphoid infiltration of white pulp and red pulp was not significantly different when compared to the normal controls. 


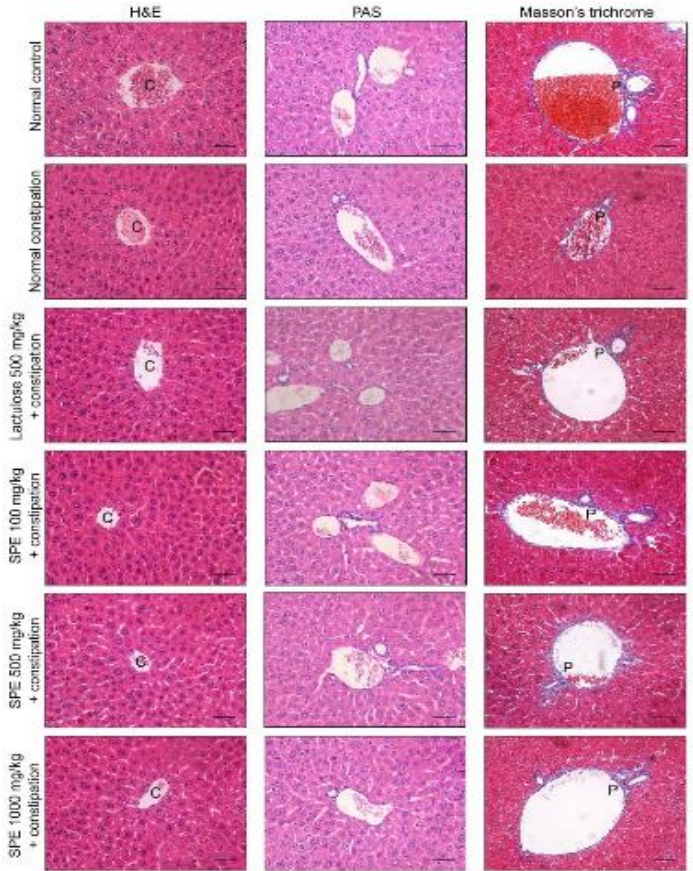

Figure 5: Effect of Sargassum plagiophyllum extract (SPE) pretreatment on the liver histology of constipated mice. The liver tissues were stained with hematoxylin and eosin (H\&E), periodic acid Schiff (PAS) and Masson's trichrome. C: central vein; P; portal triad; scale bar $=20 \mu \mathrm{m}$
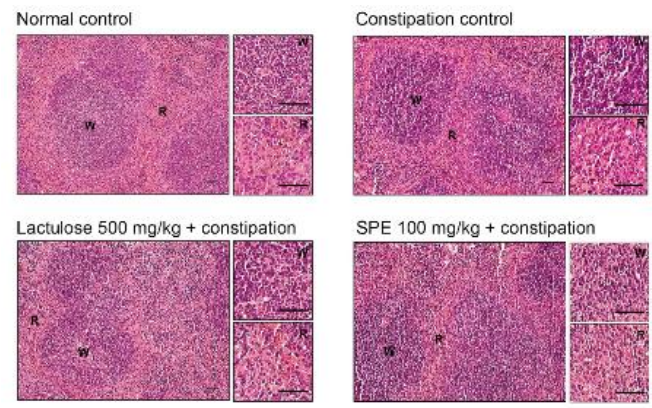

SPE $500 \mathrm{mg} / \mathrm{kg}$ + constipation
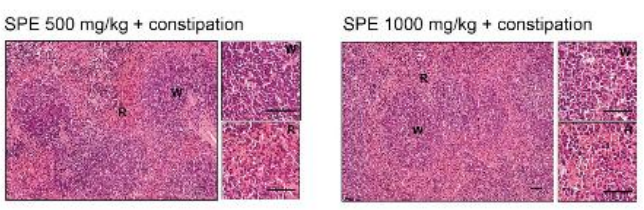

Figure 6: Effect of Sargassum plagiophyllum extract (SPE) pretreatment on the spleen histology of constipated mice. The spleen tissue was stained with hematoxylin and eosin (H\&E). R: red pulp; W: white pulp; scale bar $=20 \mu \mathrm{m}$

\section{DISCUSSION}

The antioxidant activity of SPE in this study was higher than previously reported for another Sargassum species [7], the difference may be due to species variance and the extraction method used [7]. Other studies have provided evidence that Sargassum extracts from several species are good sources of natural antioxidants [5]. Several lines of evidence indicate that the antioxidant activity of Sargassum extract is exerted through the presence of polyphenols and $\mathrm{Fe}^{2+}$-chelating ability [4]. Accordingly, SPE can possibly be recommended as an antioxidant that prevents oxidative stress by attenuating oxidative damage.

The administration of SPE changed neither body weight nor food intake and did not have detrimental effects on the growth of the experimental animals. These results are consistent with previous reports of the effects of seaweed extract on body weight [8] and food intake [9] in animal models. In a study of Wistar rats [10], the oral administration of Sargassum extract for 28 consecutive days showed no toxic effect on the epithelium of stomach and intestine. However, the numbers of goblet cells were significantly reduced in the mucosa of loperamide-induced constipation rats. The benefits of SPE pretreatment may be seen in the frequency of defecation. In a study of constipation in rats, pretreatment with SPE shortened gastrointestinal transit time, which in turn alleviated reductions in the numbers of goblet cells [11]. In ICR mice, the consumption of prebiotic extracts of dragon fruit stimulated gut motility [3]. These results suggested that SPE pretreatment increased the frequency of defecation and prevented the loss of goblet cells in constipated rats, which in turn protected the intestinal epithelium.

With regard to the effect of SPE on internal organs, the results of this study indicated that oral administration of SPE was safe. This conclusion is supported by the findings of previous reports. The administration of seaweed extract has been reported safe for the kidneys, since it did not interfere with renal functioning [8] and did not cause any alteration of renal histology [12]. It has also been reported that the administration of seaweed extract did not alter liver tissue histology or levels of serum ALT and ALS, which reflect normal liver functioning [12]. Amount of collagen fiber deposition at the portal triad also normal as this index has been used to evaluate liver injury and hepatotoxicity [13]. The consumption of seaweed extract also showed no effect on the spleen histology of Swiss mice [14]. In previous research, the major constituents of seaweed, fucoidan [15], fucoxanthin [16] and laminarin [17], showed no toxic effect on the kidney, liver, or spleen after treatment in vivo. These reports support the results of this study 
that SPE presents no risk to the kidney, liver, and spleen.

\section{CONCLUSION}

The findings of this study reveal that Sargassum plagiophyllum extract exhibits antioxidant activity, and has no toxic effect on the histology of the ileum, kidney, liver, and spleen of constipated mice. Furthermore, pretreatment with Sargassum plagiophyllum extract protects against the reduction of goblet cells in constipation mice. Therefore, these results strongly suggest that Sargassum plagiophyllum extract is a promising supplement for constipation management.

\section{DECLARATIONS}

\section{Acknowledgement}

This research was supported by National Science, Research and Innovation Fund (NSRF) and Prince of Songkla University (Grant No. SCl6405072S). This work was supported by Thammasat University Research Unit in Synthesis and Applications of Graphene. The authors would like to thank $\mathrm{Mr}$ Thomas Duncan Coyne for English proofreading of the manuscript.

\section{Conflicts of interest}

There were no conflicts of interest to declare.

\section{Contribution of authors}

The authors declare that this work was done by the authors named in this article and all liabilities pertaining to claims relating to the content of this article will be borne by them. Chittipong Tipbunjong, Saranya Peerakietkhajorn, Pissared Khuituan - conceived and designed the experiment and wrote the manuscript; Chittipong Tipbunjong, Saranya Peerakietkhajorn, Rattanaporn Sengkhim, Nilobon Jeanmard, Supattra Pongparadon, Thanvarin Thitiphatphuvanon, Piyaporn Surinlert - collected and analyzed the data; Chittipong Tipbunjong - approved final version of the manuscript. All authors read and approved the manuscript for publication.

\section{Open Access}

This is an Open Access article that uses a funding model which does not charge readers or their institutions for access and distributed under the terms of the Creative Commons Attribution License (http://creativecommons.org/licenses/by/
4.0) and the Budapest Open Access Initiative (http://www.budapestopenaccessinitiative.org/rea d), which permit unrestricted use, distribution, and reproduction in any medium, provided the original work is properly credited.

\section{REFERENCES}

1. Higgins PD, Johanson JF. Epidemiology of constipation in North America: a systematic review. Amer J Gastroenterol 2004; 99(4): 750-759.

2. $Y u T$, Zheng $Y P$, Tan JC, Xiong WJ, Wang $Y$, Lin $L$. Effects of prebiotics and synbiotics on functional constipation. Am J Med Sci 2017; 353(3): 282-292.

3. Khuituan $P, K-d a S$, Bannob K, Hayeeawaema $F$, Peerakietkhajorn S, Tipbunjong $C$, Wichienchot $S$, Charoenphandhu N. Prebiotic oligosaccharides from dragon fruits alter gut motility in mice. Biomed Pharmacother 2019; 114: 108821.

4. Liu L, Heinrich M, Myers S, Dworjanyn SA. Towards a better understanding of medicinal uses of the brown seaweed Sargassum in traditional Chinese medicine: $A$ phytochemical and pharmacological review. J Ethnopharmacol 2012; 142(3): 591-619.

5. Lim S, Choi AH, Kwon M, Joung EJ, Shin T, Lee SG, Kim NG, Kim HR. Evaluation of antioxidant activities of various solvent extract from Sargassum serratifolium and its major antioxidant components. Food Chem 2019; 278: 178-184.

6. Yende SR, Harle UN, Chaugule BB. Therapeutic potential and health benefits of Sargassum species. Pharmacogn Rev 2014; 8(15): 1-7.

7. Syad AN, Shunmugiah KP, Kasi PD. Antioxidant and anti-cholinesterase activity of Sargassum wightii. Pharm Biol 2013; 51(11): 1401-1410.

8. Balboa EM, Millán $R$, Domínguez $H$, Taboada $C$. Sargassum muticum hydrothermal extract: effects on serum parameters and antioxidant activity in rats. Appl Sci 2019; 9(12): 2570.

9. El-Waziry A, Al-Haidary A, Okab A, Samara E, Abdoun K. Effect of dietary seaweed (Ulva lactuca) supplementation on growth performance of sheep and on in vitro gas production kinetics. Turk J Vet Anim Sci 2015; 39(1): 81-86.

10. Sathiya $R$, Murali A, Jayaraman A. Phytochemical screening and toxicological evaluation of Sargassum wightii Greville in Wistar rats. Turk J Pharm Sci 2019; 16(4): 466.

11. Zhang $Y$, Ge T, Xiang $P$, Mao H, Tang S, Li A, Lin L, Wei $Y$. Therapeutic effect of protease-activated receptor 2 agonist SLIGRL-NH2 on loperamide-induced SpragueDawley rat constipation model and the related mechanism. Drug Des Devel Ther 2018; 12: 2403.

12. Premarathna $A D$, Ranahewa $T$, Wijesekera $S$, Harishchandra $D$, Karunathilake $K$, Waduge $R N$, Wijesundara RRMKK, Jayasooriya AP, Wijewardana $V$, Rajapakse RPVJ. Preliminary screening of the aqueous extracts of twenty-three different seaweed species in Sri Trop J Pharm Res, November 2021; 20(11): 2345 
Lanka with in-vitro and in-vivo assays. Heliyon 2020; 6(6): e03918.

13. Galli A, Crabb DW, Ceni E, Salzano R, Mello $T$, SvegliatiBaroni G, Ridolfi F, Trozzi L, Surrenti C, Casini A. Antidiabetic thiazolidinediones inhibit collagen synthesis and hepatic stellate cell activation in vivo and in vitro. Gastroenterology 2002; 122(7): 1924-1940.

14. Rodrigues JAG, Vanderlei EdSO, de Araujo IWF, Quindere ALG, Coura CO, Benevides NMB. In vivo toxicological evaluation of crude sulfated polysaccharide from the green seaweed Caulerpa cupressoides var. lycopodium in Swiss mice. Acta Sci Technol 2013; 35(4): 603-610.
15. Hwang PA, Yan MD, Lin HTV, Li $K L$, Lin YC. Toxicological evaluation of low molecular weight fucoidan in vitro and in vivo. Mar Drugs 2016; 14(7): 121.

16. Beppu F, Niwano Y, Tsukui T, Hosokawa M, Miyashita K. Single and repeated oral dose toxicity study of fucoxanthin (FX), a marine carotenoid, in mice. J Toxicol Sci 2009; 34(5): 501-510.

17. Shang HS, Shih YL, Chen CP, Lee MH, Lu HF, Chou PY, Liao NC, Chen YL, Hsueh SC, Chung JG. Laminarin promotes immune responses and normalizes glutamic oxaloacetic transaminase and glutamic pyruvic transaminase levels in leukemic mice in vivo. In vivo 2018; 32(4): 783-790. 